\title{
The Effect of Digital Literacy on Social Media Ethics
}

\author{
Muhammad Naufal Fadhilah', Rini Maryanti' ${ }^{2 *}$, Verra Wulandary ${ }^{3}$, Asep Rudi \\ Irawan $^{4}$ \\ ${ }^{1}$ Program Studi Ilmu Komunikasi, Universitas Pendidikan Indonesia, Indonesia \\ ${ }^{2}$ Departemen Pendidikan Khusus, Universitas Pendidikan Indonesia \\ ${ }^{3}$ Graduate School of International Development Coorperation, Hiroshima University, Japan \\ ${ }^{4}$ School of Human Sciences, University of Tsukuba, Japan \\ "Corresponding author : maryanti.rina@upi.edu
}

\begin{abstract}
Abstrak: Kurangnya pemahaman peserta didik kelas 9 Sekolah Menengah Pertama, tentang literasi digital dan etika dalam bermedia sosial tentu perlu diperhatikan. Hal ini mengingat dikarenakan teknologi yang semakin canggih, membuat siapa saja dapat mengaksesnya dengan mudah, termasuk anak-anak remaja. Dengan menggunakan asesmen literasi digital, peneliti berupaya untuk meningkatkan pemahaman tentang etika bermedia sosial. Metode penelitian yang digunakan adalah media google form dengan teknik purposive sampling. Teknik purposive sampling merupakan teknik pengambilan sampel yang didasarkan atas ciriciri atau karakteristik untuk mencapai tujuan dari penelitian ini. Responden berjumlah 10 orang peserta didik kelas 9 Sekolah Menengah Pertama, yang terdiri dari lima laki-laki dan lima perempuan. Soal yang diberikan berupa 10 soal pre-test dan 10 soal post-test. Hasil penelitian menunjukkan bahwa responden semula belum terlalu memahami etika dalam bermedia sosial. Namun, setelah pemberian materi melalui literasi digital, para responden menunjukkan perubahan yang signifikan. Responden juga terdorong untuk mulai memperhatikan etika dalam bermedia sosial.
\end{abstract}

Kata Kunci: etika, literasi digital, media sosial

Abstract: The lack of understanding of grade 9 students of junior high school, about digital literacy and social media ethics needs to be considered. This is because technology is increasingly sophisticated, making it easy for anyone to access it, including teenagers. By using a digital literacy assessment, researchers seek to increase understanding of social media ethics. The activity method used is google form with purposive sampling technique. Purposive sampling technique is a sampling technique based on characteristics to achieve the objectives of this study. The respondents were 10 students in grade 9 of junior high school, consisting of five male and five females. The questions given are in the form of 10 pre-test questions and 10 post-test questions. The results showed that respondents did not really understand social media ethics. However, after giving the material through digital literacy, the respondents showed a significant change. Respondents are also encouraged to start paying attention to social media ethics.

Keywords: digital literacy, ethics, social media 


\section{Introduction}

Today, technological developments are increasingly prevalent. People have started to make a transition to the media they use, where initially using conventional media turned into new media. As we know, conventional media is the same as traditional media, which usually consists of electronic media and print media. Electronic media includes television and radio, while print media includes magazines, newspapers, brochures, etc. Meanwhile, new media are internet-based media, such as websites or social media. This new media is actually a medium that experiencing rapid conceptual change along with the acceleration of computer technology, internet and digital telecommunications (Darwadi, 2017). Then, to find out how many internet users in Indonesia, the researchers took data collected from Databoks. Databoks is a portal that displays a lot of statistical data in the economic and business fields, and is still part of Katadata. Reporting from databoks.katadata.id, according to Internetworldstats, internet users in Indonesia reached 29.35 million out of a total population of 276.3 million. Furthermore, the Central Statistics Agency (BPS) in 2019 noted that $48.2 \%$ of Indonesian children aged 7-17 years have accessed the internet. Of this number, $75.8 \%$ of children who access the internet use it for social media.

Social media can be said as a platform that focuses on the existence of users in their activities or collaboration (Setiadi, 2016). In addition, social media can also be said as a collection of software that allows individuals or communities to gather, share, communicate, collaborate, and play in the same container. Social media has characteristics that are not much different from conventional media, but there are some special characters that social media has, such as networks, information, archives, interactions, social simulations, and content. In addition, social media also has several types, including social networking, blogs, microblogging, media sharing, social bookmarking, and content media (Setiadi, 2016).

According to the Merriam-Webster dictionary, social media is defined as a form of communication in the form of websites for social networks, where users can create online communities to share information, ideas, private messages, and other content (Edosomwan, 2011). In another sense, anyone can access social media without experiencing difficulties. In fact, it is possible for children to the elderly to be able to access social media. In social media, content that was originally private can become public property. Everyone should have personal awareness, that anything uploaded to social media can affect self-image and relationships with other parties (Rawanoko, 2021). Even though it talks about freedom of expression, you still have to adhere to the ethics of communication and good self-control (Anwar, 2017). 
Often the use of social media is not accompanied by knowledge of the ethics of using social media. The ethical violations in question are spreading false news, triggering online crimes, online fraud, etc (Candraningrum, 2018). In order to overcome these problems, of course, a deep understanding is needed before using social media, especially since this has been regulated in Law no. 11 of 2008, concerning information and electronic transactions, or information technology in general (UU ITE). One way that can be used to avoid being entangled in ethical violations in social media is by doing literacy. Digital literacy itself is intended so that a person not only has the ability to use various sources of information, but also as a form of way of thinking. In other words, digital literacy can be used to protect yourself from media exposure, so you can think critically. Meanwhile, the level of digital literacy in Indonesia itself is still not very good. Reporting from Kominfo, based on the results of a survey on Indonesia's digital literacy status, from a scale of 1 to 4 , Indonesia's digital literacy index is still at 3.47 and is still below a good level.

Understanding of technology and information capabilities should have been taught from an early age. Adolescents who have good digital literacy skills will generally be able to think critically, and be able to express their thoughts well (Pratiwi \& Pritanova, 2017). Literacy comes from the Latin literra or letters, which means it involves everything about mastering the writing system and other related aspects (Darwadi, 2017). Digital literacy can be defined as the ability of an individual to use digital technology and communication tools to access, analyze, and evaluate information (Asari, 2019). Digital literacy can also be used to demonstrate the basics of new media, namely digitalization (Amalia, 2015).

Digital literacy is one part of media literacy. The key to media literacy is to build a good knowledge structure (Darwadi, 2017). In another sense, media literacy also aims to provide knowledge to an individual through the writings that are analyzed. Digital literacy is needed so that everyone can participate in the modern world, and anticipate the spread of negative information (Sutrisna, 2020). The more often someone does literacy, the more that person understands the conditions that occur, so that in the end tends to minimize the occurrence of ethical violations in social media. Therefore, it is important to carry out digital literacy in order to understand and anticipate the occurrence of ethical violations in social media. Based on the explanation above, the researcher is interested in conducting a activity entitled "The Effect of Digital Literacy on Social Media Ethics (Study on Grade 9 Students of Junior High School)". 


\section{Methods}

This background in understanding digital literacy skills from an early age will later affect students' ethical behavior in social media. For this reason, this study was designed using activity methods with descriptive methods and quantitative approaches in the hope that students are able to provide concrete and statistically accurate data. The quantitative method itself is a activity method based on the philosophy of positivism which is used to examine certain samples by taking them at random with the results in the form of statistical data which will be tested for predetermined hypotheses (Darna \& Herlina, 2018).

The sampling technique used is purposive sampling, namely the technique used by taking a limited sample with a specific target group with several criteria determined by the researcher (Mulyadi, 2018). Later, several 9th grade junior high school students, totaling 10 respondents, namely five boys and five girls will be the object of activity with several qualifications such as using social media actively. As well as the data collection technique used in the form of a questionnaire in the form of a google form which is divided into pre-test and post-test with the aim of knowing the ability of students to absorb information that has not been and is already known.

The scoring in this activity questionnaire uses a dichotomous scale technique to provide several possible scores to choose from and the answer to each instrument is in the form of yes or no (Pudyastuti, 2021). By using two existing indicators, namely digital literacy and ethics in social media, this is the basis for the questionnaire in the form of pre-test and post-test with 10 questions each. The results of the questionnaire will be analyzed further by referring to how digital literacy is in students' ethics in social media described in the previous chapter

\section{Results and Discussion}

\subsection{Demography}

This activity was conducted at junior high school. The first step in this study was to survey the number of students in the school by interviewing the principal. Then the researcher selected a sample from the population and obtained as many as 10 students. Based on Fig. 1 and Fig. 2 , all students with details of male as many as 50\% (5 students) and female as many as $50 \%$ (5 students). and all of them using social media. 
Jurnal Abdimas Kartika Wijayakusuma ISSN 2716-3512 (Online) ISSN 2721-0367 (Print)
This work is licensed under a Creative Commons Attribution-ShareAlike 4.0 International License.

CC BY SA

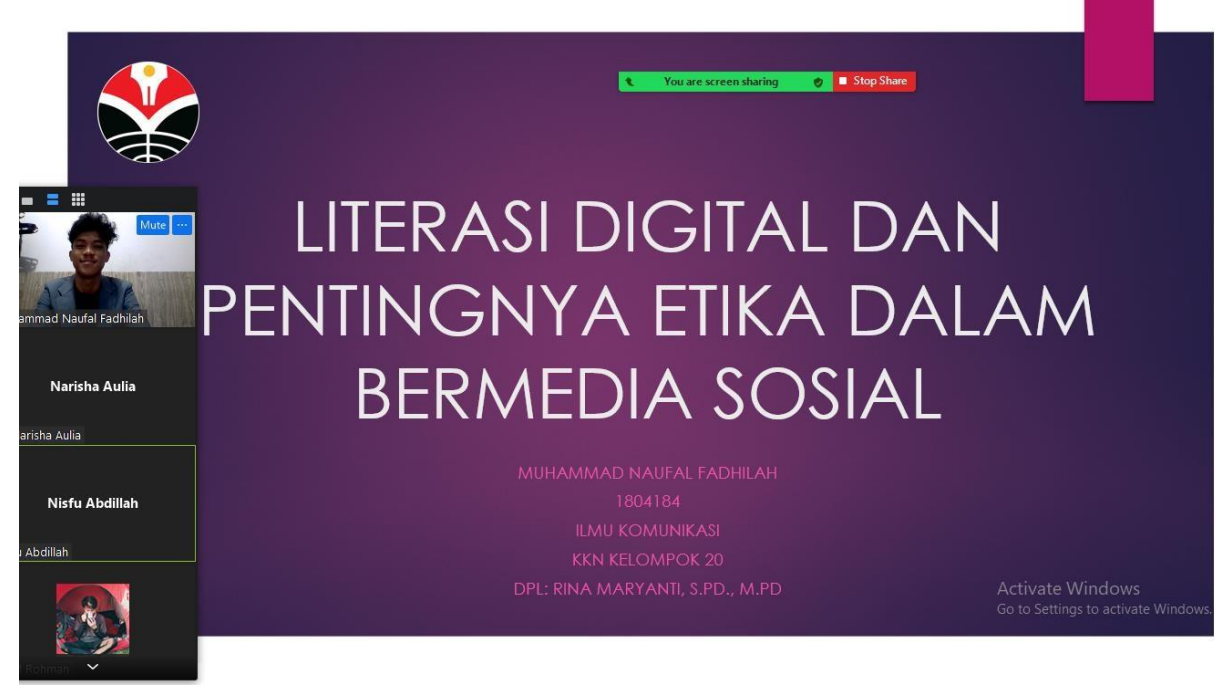

Fig. 1. Material Delivery about Digital Literacy and Social Media Ethics

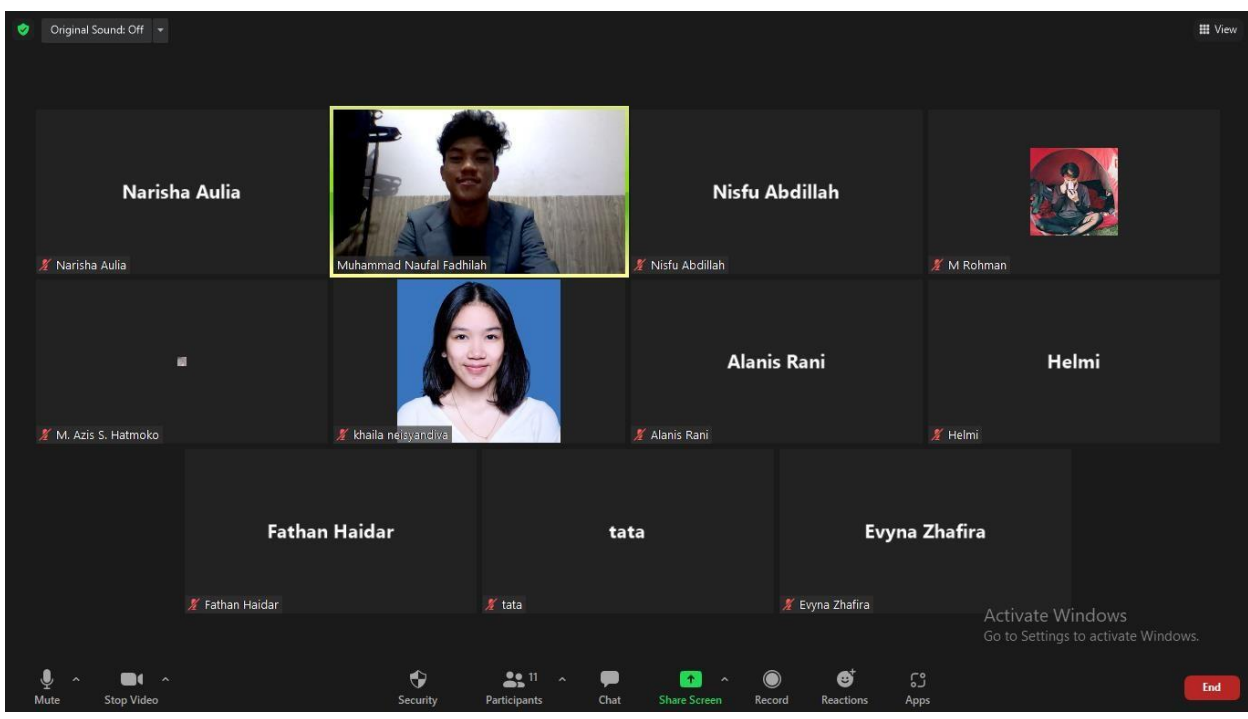

Fig. 2. All Students Grade 9 Junior High School

\subsection{Pre-test and Post-test Results}

Learning activities at junior high school are carried out online. Tools and media used in learning through google form. Researchers introduced google form to students through video calls via zoom. This method is an interactive learning about digital literacy and social media ethics.

Table 1 describes the questions that have pre-test and post-test proposed. The first questionnaire that was made was a pre-test questionnaire. The making of this questionnaire was distributed to students of 9 grade of junior high school, which aims to find out how far they understand about digital literacy and social media ethics is by filling out 10 questions. 
After that, the researcher will provide that digital literacy is important for social media ethics is. After explaining the material, the researcher redistributed the questionnaire with the same question, namely in the form of a post-test to the students with the aim of understanding the material for the the social media ethics.

Table 1. Students' pretest and posttest results.

\begin{tabular}{|c|c|c|c|c|}
\hline Number & Question & Pre-Test & Post-Test & Gain \\
\hline 1. & $\begin{array}{l}\text { Did I understand about } \\
\text { digital literacy? }\end{array}$ & $80 \%$ & $100 \%$ & $20 \%$ \\
\hline 2. & $\begin{array}{l}\text { I have the ability to process } \\
\text { the information on social } \\
\text { media? }\end{array}$ & $100 \%$ & $100 \%$ & $0 \%$ \\
\hline 3. & $\begin{array}{l}\text { I have the ability to analyze } \\
\text { content on social media? }\end{array}$ & $80 \%$ & $100 \%$ & $20 \%$ \\
\hline 4. & $\begin{array}{l}\text { Can I sort and select } \\
\text { information on social } \\
\text { media that has benefits? }\end{array}$ & $100 \%$ & $100 \%$ & $0 \%$ \\
\hline 5. & $\begin{array}{l}\text { Can I create content that is } \\
\text { ethical in social media? }\end{array}$ & $80 \%$ & $100 \%$ & $20 \%$ \\
\hline 6. & $\begin{array}{l}\text { Did I understand ethics in } \\
\text { social media? }\end{array}$ & $50 \%$ & $100 \%$ & $50 \%$ \\
\hline 7. & $\begin{array}{l}\text { I understand what is } \\
\text { allowed or not allowed on } \\
\text { social media? }\end{array}$ & $60 \%$ & $100 \%$ & $40 \%$ \\
\hline 8. & $\begin{array}{l}\text { I understand that is social } \\
\text { media it is necessary to } \\
\text { speak good words? }\end{array}$ & $60 \%$ & $90 \%$ & $30 \%$ \\
\hline 9. & $\begin{array}{l}\text { I understand that social } \\
\text { media should not offend }\end{array}$ & $100 \%$ & $100 \%$ & $0 \%$ \\
\hline 10. & $\begin{array}{l}\text { I understand that social } \\
\text { media should not offend } \\
\text { SARA }\end{array}$ & $100 \%$ & $100 \%$ & $0 \%$ \\
\hline
\end{tabular}

The results show several discussion points:

(i) For question number one the result increased by $20 \%$ when the material on the meaning of digital literacy and social media ethics was given.

(ii) For question number two the results is same when the understanding of process information was given.

(iii) For question number three the result increased by $20 \%$, presented material on the ability to analyze content on social media was given.

(iv) For question number four the results is same when the understanding of sort and select information on social media was given. 
(v) For question number five the results increased by $20 \%$ when the material of created content was given.

(vi) For question number six the result is quite increased by $50 \%$ when the material of social media ethics was given.

(vii) For question number seven the result increased by $40 \%$ when the material of allowed and not allowed on social media was given.

(viii) For question number eight the results increased $30 \%$ when the material of speaking good words on social media was given.

(ix) For question number nine the results is same after being given the material of social media should not offend people.

(x) For question number ten the result is same after being given the material of social media should not offend SARA.

Based on the results of the first survey in pre-test regarding understanding digital literacy, $80 \%$ of respondents understand what digital literacy is, while the other $20 \%$ answered no. Then, the majority of respondents know how to process and select information, analyze, and create content on social media.

Furthermore, the results of the first survey in pre-test on understanding social media ethics show that $50 \%$ of respondents understand social media ethics, while the other $50 \%$ do not. Likewise, about things that can and cannot be done on social media, as well as issues of speech in social media, $60 \%$ of respondents answered yes, while $40 \%$ of respondents answered no. However, all respondents knew that they should not offend and offend SARA towards other people.

Based on the results of the second survey, post-test shows a significant change. If initially some respondents did not understand digital literacy, how to analyze and create content, this time all respondents began to understand after being given an explanation. This is evidenced by a graph that shows $100 \%$ results. Meanwhile, there are still people who don't understand well in choosing information, as evidenced by $90 \%$ answering yes and $10 \%$ answering no.

Furthermore, the second survey of post-test on the understanding of social media ethics showed very significant results. If previously some of the respondents did not know the ethics of social media, what can and cannot be done, and must speak good words, now all respondents have begun to understand it. This is evidenced by the results of $100 \%$ of respondents understanding social media ethics. Meanwhile, regarding good speech in social media, 90\% answered yes, and $10 \%$ answered no. 


\section{Conclusion}

Based on the activity that has been done, the researcher can conclude that the 9th grade students of Junior High School, can complete the questionnaires given well. The questions consist of 10 pre-test questions and 10 post-test questions. The researcher also concluded that the ability of grade 9 students at junior high school, who initially did not understand digital literacy and ethics in social media, became more understanding after being given the material.

In addition, researchers suggest that socialization related to understanding digital literacy and the importance of ethics in social media be carried out since adolescence, because it is possible that many young people have used social media in their daily lives. Then, both teachers and parents are expected to always remind what can and cannot be done on social media, because what is uploaded on social media can become a digital footprint and consumption for the public.

\section{Acknowledgement}

We acknowledged Bangdos, Universitas Pendidikan Indonesia. We thank to Ii Syamsul Farid, S.Pd. from SMP Negeri 1 Ibun. This study is a part of community service (Program: KKN Tematik Literasi 2021 (August-Sept 2021) kelompok 20) Lembaga Penelitian dan Pengabdian Masyarakat (LPPM), Universitas Pendidikan Indonesia. We also thank to Kantor Jurnal dan Publikasi, Directorate of International Affairs, Universitas Pendidikan Indonesia. We thank to Nissa Nur Azizah, Dwi Fitria Al Hussaeni, Dr.Eng. Asep Bayu Dani Nandiyanto, S.T., M.Eng., Muktiarni, S.Pd., M.Pd., and Asri Wibawa Sakti, M.Pd.. 


\section{References}

Amalia, R. R. 2015. Literasi digital Pelajar SMA: Kemampuan berkomunikasi dan berpartisipasi pelajar SMA negeri di Daerah Istimewa Yogyakarta melalui internet.Jurnal Studi Pemuda, 4(1), 224-240.

Anwar, F. 2017. Perubahan dan permasalahan media sosial. Jurnal Muara Ilmu Sosial, Humaniora, dan Seni, 1(1), 137-144.

Asari, A. 2019. Kompetensi literasi digital bagi guru dan pelajar di lingkungan sekolah Kabupaten Malang. Jurnal Kajian Perpustakaan dan Informasi, 4(1), 98-104.

Candraningrum, D. A. 2018. Etika dan budaya berinteraksi di media sosial. Jurnal Bakti Masyarakat Indonesia, 1(1), 1-9.

Darna, N., \& Herlina, E. (2018). Memilih metode penelitian yang tepat: Bagi penelitian ilmu manajemen. Jurnal Ilmu Manajemen, 5(1), 287-292.

Darwadi. 2017. Media baru sebagai informasi budaya global. Jurnal Komunikator, 9(1), 39-48.

Edosomwan, S. 2011. The history of social media and its impact on business. The Journalof Applied Management and Entrepreneurship, 16(3), 1-13.

Mulyadi, A. 2018. Pengaruh kepercayaan, kemudahan, dan kualitas informasi terhadap keputusan pembelian di toko online Lazada. Jurnal Ilmiah Manajemen Bisnis danTerapan, 15(2), 87-94.

Pratiwi, N. \& Pritanova, N. 2017). Pengaruh literasi digital terhadap psikologis anak dan remaja. STKIP Siliwangi Journals, 6(1), 11-24.

Pudyastuti, A. T. 2021. Efektivitas pembelajaran e-learning pada guru PAUD selamapandemic Covid-19. Jurnal Pendidikan Anak Usia Dini, 5(2), 1667-1675.

Rawanoko, E. S. 2021. The use of social media in ethic digital perspective. Jurnal Civics: Media Kajian Kewarganegaraan, 18(1), 148-157.

Setiadi, A. 2016. Pemanfaatan media sosial untuk efektifitas komunikasi. Jurnal Humaniora, 16(2), 1-7.

Sutrisna, I. P. 2020. Gerakan literasi digital pada masa pandemi Covid-19. JurnalPendidikan Bahasa dan Seni, 8(2), 268-283. 